\title{
Cooperation in the Field of Public Health and Medicine: Instances of Expert and Knowledge Mobility between Vienna, Zagreb and the Far East
}

\author{
Željko Dugac ${ }^{1}$
}

${ }^{1}$ Croatian Academy of Arts and Sciences, Divison for the History and Philosophy of Science,

Department of Philosophy of Science, Ante Kovačića 5, Zagreb

ABSTRACT:

In this essay the transfer of knowledge and experts between Vienna, Zagreb, inter-war China and the USSR will be analysed through the collaboration between two well-known interwar public health reformers, Austrian Julius Tandler and Croat Andrija Štampar. In the 1930s, they worked in China under the auspices of the League of Nations Health Organization and developed intensive cooperation in the field of public health. Based on the diary records of Andrija Štampar and the preserved archival correspondence, their personal and professional contacts were analysed. The main interest was the exchange of experiences and opinions, as well as their observations about the people and ideas they encountered and the situations in which they found themselves. This essay also tries to shed some light on the milieu in which the notions of public health and social medicine advanced, as well as the multiple external factors which influenced those developments. However, the opportunities for constructive work in the field of public health grew increasingly slim in the political constellation of the time. The League of Nations was losing its power and its health organisation followed suit. The local resistance to foreign influences in China was becoming progressively intense. The ever more severe unrest led the world into World War II and pushed the establishment of an international public health order to the margins for some time to come. However, what remained in memory was a flow of ideas and experiences which was formed in Central and Southeastern Europe and which subsequently tried to make their way far to the East and develop not only local but also general and international qualities. Many of these ideas became the basis for a new world-wide public health system that developed after World War II.

KeYwordS: Julius Tandler, Andrija Štampar, China, interwar period, history of medicine, history of public health

\section{SAŽETAK:}

SURADNJA U PODRUČJU JAVNOG ZDRAVLJA I MEDICINE: PRIMJERI TRANSERA ZNANJA I STRUČNJAKA IZMEĐU BeČa, Zagreba i Dalekog istoka

U ovom su radu predstavljeni transfer znanja i stručnjaka između Beča, Zagreba, međuratne Kine i SSSR-a kroz suradnju dvaju poznatih međuratnih reformatora javnog zdravstva, Austrijanca Juliusa Tandlera i Hrvata Andrije Štampara. Ta su dva javnozdravstvena stručnjaka 1930-tih radili u Kini pod pokroviteljstvom Zdravstvene organizacije Lige naroda i razvijali intenzivnu suradnju u području javnog zdravstva i medicinske nastave. Na temelju dnevničkih zapisa Andrije Štampara i sačuvane arhivske korespondencije analizirani su njihovi osobni i profesionalni kontakti. Glavno zanimanje ovog rada se veže uz razmjenu njihovih iskustava i mišljenja, kao i njihova zapažanja o ljudima i idejama s kojima su se susreli te situacijama u kojima su se našli. Ovaj rad također pokušava osvijetliti milje u kojem su se javno zdravstvene i socijalno medicinske ideje razvijale kao i vanjske čimbenika, nevezane uz samu struku, koji su utjecali na njih. Krajem 30-tih godina 20. stoljeća prilike za konstruktivan rad na području javnog zdravstva postajale su sve slabije a pod utjecajem tadašnje političke konstelacije i gubita utjecaja Lige naroda. Lokalni otpor stranim utjecajima u Kini postajao je sve intenzivniji. Sve oštriji nemiri vodili su svijet u Drugi svjetski rat i gurnuli uspostavljanje međunarodnog javnozdravstvenog poretka u posve drugi plan. Međutim, ono što je ostalo u naslijeđe je bio protok ideja i iskustava koji je zahvatio ne samo lokalno područje Srednje i Jugoistočne Europe već se proširio sve do područja Dalekog istoka. Mnoge od tih ideja postale su temelj novog svjetskog javnog zdravstvenog sustava koji se razvio nakon Drugog svjetskog rata.

KLJUČnE RIJEČI: Julius Tandler, Andrija Štampar, Kina, međuratno razdoblje, povijest medicine, povijest javnog zdravstva

OPEN ACCESS

Correspondence: Prof Željko Dugac PhD dugac@hazu.hr

This article was submitted to RAD CASA - Medical Sciences as the Essay

Conflict of Interest Statement: The author declare that the research was conducted in the absence of any commercial or financial relationships that could be construed as a potential conflict of interest.

Received: 10 November 2019 Accepted: 24 November 2019 Published: 17 December 2019

Citation:

Dugac Ž. Cooperation in the Field of Public Health and Medicine: Instanc es of Expert and Knowledge Mobility between Vienna, Zagreb and the Far East. RAD CASA - Medical Sciences. $540=48-49$ (2019): 78-85. https:// dx.doi.org/10.21857/y7v64t56ny

Copyright (C) 2019 Dugac. This is an open-access article distributed under the terms of the Creative Commons Attribution License (CC BY). The use, distribution or reproduction in other forums is permitted, provided the original author(s) and the copyright owners(s) are credited and that the original publication in this journal is cited, in accordance this journal is cited, in accordance whit accepted adacemic practice. No use, distribution or reproduction is permitted which does not comply with these terms. 


\section{INTRODUCTION}

Cooperation in the field of public health and medicine is a case in point of the mobility of intellectuals and expertise in Central and Southeastern Europe in the first decades of the $20^{\text {th }}$ century which allows us to take stock of its manifold features. In this essay, I am going to address a lesser-known and under-researched issue - the transfer of knowledge and experts between Vienna, Zagreb, inter-war China and the USSR.

I would thus like to bring to light some of the details concerning the cooperation and mutual contact between two widely-known public health reformers, Austrian Julius Tandler and Croat Andrija Štampar. In the 1920s, the former worked on public health reform in Austria, while the latter acted in the Kingdom of Yugoslavia, following which both transferred their knowledge and experience to China in the 1930s, with Tandler attempting to do so in the USSR, as well. Julius Tandler's cooperation with the USSR health administration, which had started in February 1936, ended because of Tandler's death in August 1936. Andrija Štampar paid a study visit to the country the same year. Therefore, rather than constituting any actual type of cooperation, which can only be questionable, this could be described as a merely conceptual exchange of ideas and a scan of the situation and the possibilities at hand.

Štampar was a student of Tandler's at the Faculty of Medicine in Vienna. The two went on to become colleagues in the area of public health work in their respective home countries and subsequently found themselves working as university professors and medical experts in China and the USSR in the 1930s. Both Štampar and Tandler were employed by the Chinese administration and were also members of an expert team brought together by the Health Section of the League of Nations to provide support in the training of staff and the standardization of both medical education and health service provision in line with Western standards and the international norms of the day. ${ }^{1,2,3}$ In this chapter, my intention will not be to reflect in greater detail on Štampar's and Tandler's work in China and the USSR, considering the fact that that part of their life stories has already been expounded upon to a fair extent, particularly as far as Štampar is concerned. I am rather going to principally focus on their mutual exchange and interactions ${ }^{4}$. In other words, my concern will be their exchange of experiences and opinions, as well as their observations about the people and ideas they encountered and the situations in which they found themselves. By looking more closely into this, I will try to shed some light on the milieu in which the notions of public health and social medicine advanced, as well as the multiple external factors which influenced those developments.

For this analysis, I have largely relied on the writings of Andrija Štampar found in his personal journal, which he kept from 1931 to 1938, during a period of intensive international activity and frequent travel on his part. In addition to this, my analysis has benefitted greatly from the written correspondence between Tandler and Štampar, which is kept in the archives of the Josephinum Institute for the History of Medicine in Vienna. For this essay I also used archival material kept at the University Archives in Vienna and parts of the Andrija Štampar's diary published in 2008.

\section{A MEETING BETWEEN STUDENT AND PROFESSOR, COLLEAGUES AND FRIENDS}

Tandler's and Štampar's relationship transformed from one between student and professor at university to one between colleagues, as well as friends in later years. In the 1930s, many European intellectuals and public health reformers were forced to leave their academic and administrative posts because of the rise of political extremism which finally led to the emergence of fascism. In 1931, Štampar was compelled to unwillingly retire from his position in the Kingdom of Yugoslavia, which led him to pursue the only possible opportunity to continue with constructive public health work - at the League of $\mathrm{Na}$ tions Health Organisation (LNHO). The LNHO was an organisation which was trying to sustain an international reformist environment among its members and was therefore used as an assembly forum by experts who had suddenly become ideologically unsound after the political changes in their home countries. Štampar and Tandler were merely two in a line of other experts with similar life stories, such as the German professionals who fled fascism. In a note found in one of Štampar's letters to Tandler in 1933, one sees that Štampar was using personal contact to learn about people who had found themselves in trouble in order to transfer them to a new place of employment. In Štampar's words: "I am certainly travelling to Germany. I hope to see you in Vienna. Could you recommend me any candidates for an anatomy and physiology professorship in Nanjing and send me their names forthwith to Zemun? ${ }^{5}$ The Italian-Spanish public health reformer and malariologist Gustavo Pittaluga faced much the same, as he was also forced to leave Spain during the period. ${ }^{6}$

Julius Tandler was born in 1869 in Jihlava in the the Czech region of Moravia. He was an Austrian physician, a professor of anatomy at the University of Vienna, a Social Democratic politician and a public health reformer. He graduated at the Faculty of Medicine in Vienna on 27 July $1895 .{ }^{7}$ He was first employed at the same Faculty as a member of the teaching staff in 1910. From 1914 to 1917, during World War I, Tandler was also dean of the faculty. Though known as an anatomist, Tandler was extraordinarily involved in the field of public health and social medicine. After the end of World War I, he became health advisor at the Viennese Department of Health, where he made exceptional advancements with respect to public health and social development. In addition to this, in 1930 Tandler took on the position of advisor to the League of Nations Health Organisation. With the ascent of fascism in Austria, Tandler leaves his post and emigrates from the country to China and later to the former Soviet Union. ${ }^{8}$

Andrija Štampar was born in 1888 in the small town of Drenovci in the Croatian region of Slavonija. Having graduated from high school in the city of Vinkovci in 1906, he followed in the footsteps of his many other young Croatian compatriots to study medicine in Vien- 
na, the capital of the Austro-Hungarian Monarchy. At the time, the University of Vienna was home to numerous distinguished professors and scholars such as Carl Toldt, Julius Wagner-Jauregg, Hans Chiari and others, some of whom later became Nobel laureates. However, the lectures which impressed Štampar the most were not held by such lofty luminaries but by lecturers who spoke of an inceptive science which had still not had gained enough supporters - social medicine. It is an undeniable fact, which stems from Štampar's later work, that his development was to a significant degree influenced by Ludwig Teleky ${ }^{9}$, a socially oriented lecturer at the Faculty of Medicine in Vienna, whose courses in social medicine were taken by Štampar in the 9th semester of his studies (academic year 1910/1911). ${ }^{10}$ Besides taking social medicine classes at the Faculty of Medicine, Štampar also attended Julius Tandler's lectures on topics concerning social medicine at Vienna's Open University. This marked the beginning of a long-lasting and deep professional connection, a sharing of common views on social medicine and finally of a personal friendship.

Having graduated from his medical studies in Vienna and upon the award of his diploma on the 23rd of December 1911, Andrija Štampar returns to Croatia. ${ }^{11}$ In 1919, soon after the establishment of the Kingdom of Serbs, Croats and Slovenes, Štampar is given an important position in the country's health administration, becoming the Head of the Department of Hygiene at the newly formed Ministry of Public Health. He occupied the post until his retirement in 1931, during which time he accomplished the tremendous task of raising public health standards in an economically and hygienically underdeveloped country laden with war-caused deprivation and rife with epidemics. Enthusiastic about the ideas of social medicine, Štampar undertakes the effort of building a completely new kind of public health system by establishing a series of health institutions for social medicine and preventive healthcare. Štampar raised the public healthcare services to a level hitherto unknown not only in Central and Southeastern Europe but also beyond. In addition to this, he instituted education programs for a wide variety of medical personnel and developed additional professional training for physicians, as well as an entire range of health education and promotion campaigns which reached even the most remote rural parts of the country. Štampar is joined in his work by a line of progressive young physicians, medical nurses, engineers, artists, writers and painters, each acting in their respective field to promote and disseminate new scientific insights, new forms of public healthcare and hygiene practices, as well as a novel culture of life at large. All this took place with the goal of suppressing the spread of transmittable diseases which had at the time been the principal cause of morbidity and mortality amongst the population. ${ }^{12}$

The latter activities were most comprehensively carried out by the School of Public Health in Zagreb. The school was established in 1926 and its new grounds opened a year later, in 1927, with the financial support of the Rockefeller Foundation. It was at that time that the School of Public Health became the central institution responsible for the implementation of new and complex forms of public healthcare work. In addition to this, Štampar initiated a range of organised activities aimed at establishing various laboratories with educated staff who procured the technology needed for the production of different immunological and serological preparations, which were in turn the precondition for the fabrication of diverse vaccines for the population. With the financial assistance of the Rockefeller Foundation in Zagreb, the laboratory established at the School of Public Health set up the technological equipment for the production of Neosalvarzan, a particular type of drug against syphilis. By doing so, the laboratory joined the ranks of only a small number of other institutions in $1930 \mathrm{~s}$ Europe which had been producing a completely modern kind of medication. ${ }^{13}$

When the political environment changed at the beginning of the 1930s, Štampar was forced to leave the country and find work abroad, which marked the beginning of what would be a very rich international career under the auspices of the League of Nations Health Organisations. In 1932, he comes to China as an LNHO expert to occupy the post of healthcare advisor to Chiang Kai-shek's government. From 1932 to 1936, Štampar visits China on three separate occasions, each taking an extended period of time, as his journal shows in great detail. During his stays in China, Štampar addressed many issues of public health, trying to organise healthcare services in this vast country much like he had previously done in the Kingdom of Yugoslavia. In the process, he took part in organising and promoting Western-style education among Chinese physicians, medical nurses and midwives. Working in such a large and populous country, which was moreover constantly ridden with war and tumult, was not an easy task. In his endeavours, Štampar encountered numerous problems which, among other things, often concerned ideological differences. As is widely known, he was congenial to social ideas which had at the time seemed quite radical. However, Štampar also found many associates and like-minded professionals among his Chinese peers, in addition to a number of Westerners who had come to China to find employment. ${ }^{4}$ One of his colleagues in this business was his former professor and old friend Julius Tandler.

\section{TANDler and Štampar in AND AROUnd China AND the USSR} The possibility of establishing Tandler in China while also making use of his expertise stirred correspondence between Štampar and Tandler concerning the manner in which such a possibility might be materialized. By 1933, Štampar had already travelled to China on one occasion and was preparing for another visit to the country and the continuation of his work there. That was why, in a letter to Štampar, Tandler discusses the possibility of going to China, writing: Surely you remember our last conversations about China! I just received an invitation from Mr. Yen to spend a few months in Shanghai and also hold lectures in anatomy there. I have already tentatively given him my consent and am currently handling the matter of how to bring this journey about. I should need to make my way there at the end of August. Naturally, provided that the political situation allows this. None- 
theless, it would be of particular importance for me to know how the League of Nations sees this matter, although it does not concern the organisation directly. I imagine that the League of Nations may task me with a mission of its own, too, but I find it equally imaginable that it might be better for me not to inform the Committee for Hygiene about my plans at all, considering the differing opinions of the Committee and myself about the training of physicians in China. It might come to pass that the Chinese government burdens me with this problem at once! And you know that I am a bad representative of diplomatic medicine! Seeing as we have already spoken of this issue several times, as well as expressed our common desire to travel to China together, I am informing you of all this and asking you for your opinion and advice. You might possibly - should you find it the right thing to do, of course - inform e.g. Reichmann in whichever way suits you that you have learned about my intention. I leave that all to you. ${ }^{14}$

In his reply to the letter, Štampar writes: During the time of the recent events in your country, I thought of you very often and was quite worried about your exceptional work... From your letter I have learned that the Faculty of Medicine in Shanghai had invited you to stay in China for a few months. I am acquainted with most of the gentlemen at the Faculty of Medicine in Shanghai and I believe the school to be the finest in China. Dr Yen, the dean of the faculty, is a remarkable man who managed to acquire funding for his institution during the gravest financial crisis. I think he is currently taking efforts to continue with institution building. Dr Bume is there, too. In my opinion, you were right in accepting the invitation. With the support of the League of Nations, numerous scholars have previously been invited to those faculties and, during my travels in China, I have met many foreign lecturers at institutions of higher education who had been invited there by the Chinese authorities. I have not had the opportunity to talk about these matters with Reichmann and I do not know what he thinks about them. One thing is certain: not everything needs to be executed through the League of Nations. I do not believe that the political situation in China will add difficulty to your journey. In today's circumstances, various developments are bound to take place in such a large country, which is merely a part of the common flow of things. However, in my opinion, in no other country than China can so much can be seen, learned and done today. I am deeply convinced that you will see and find extraordinary things, considering your knowledge and experiences...Seeing as you have received an invitation from a Chinese university, I find that the Committee for Hygiene could have done well to entrust you with some sort of mission; it seems to me that diverse opinions of well-known experts on various issues should be collected in a country such as China; only that way will we come to a somewhat appropriate institution building programme; I do not know if Reichmann shares my opinion or how strong his wish to do so is; however, I will not miss the chance to discuss the matter with him. In any case, I will inform Reichmann about the invitation you received... ${ }^{15}$
As planned, Tandler was thereupon sent to China, which encouraged discussion about plans for the autumn of 1933. In one letter dating from October of that year, Štampar says: I was very happy to hear from Dr Liu, the director of the Health Service, that he had invited you to Jiangsu and Nanjing. As per the itinerary, we are going to meet on our journey to Jiangsu and spend three days travelling together. Upon your return from Jiangsu Province, you are going to come to Nanjing. ${ }^{16}$ Dr Liu J. Heng was a surgeon who was responsible for the health sector as member of Chian Kai-shek's regime, while also acting as the director of many significant institutions in China: he was the Director of the Nanjing Hospital and the Institute of Hygiene in Nanjing, the country's capital at the time, the Head of the Army Medical Corps, Chair of the Committee for Opium Abuse Prevention, Director of the Faculty of Medicine in Beijing etc.

Štampar's journal offers much greater insight into their encounters and the situational contexts in which they found themselves working. In his journal, for example, Štampar states: This evening, I am visiting Professor Tandler, who arrived to hold anatomy lectures at the Chinese medical school two weeks ago. I felt sorry when I saw him because I suddenly realized this man's tragedy: he had dedicated his entire life to the advancement of his country and used his position as chief of health care in Vienna to create one of the world's best health organisations, only to be forced to flee the circumstances in Austria, for which he neither has the propensity nor the aptitude, and to spend his old days in the Far East among foreign folk who cannot understand him, let alone comprehend the tragedy of his soul. He told me that his impressions of the country were at first utterly unfavourable; however, the other day he had witnessed the presentation of a new city building in the Chinese part of town which had been torn down last year. The Chinese youth whom he'd seen at the event made him convinced that white people had no business here in 30 years. We parted by agreeing on a schedule for our future meetings; for instance, we agreed that he would soon come to Nanjing and that we would go to Beijing together around Christmas. ${ }^{6}$

Štampar also dedicates a special chapter in his journal to Tandler, titling it "My Teacher Professor Tandler". In it, he writes: As if he had sensed how future events would unfold, despite his now old age, Professor Tandler accepted an invitation from the Faculty of Medicine in Shanghai to teach a course in anatomy in the winter semester. I had met with him several times and was not able to convince him surely enough how things in Austria would unravel. In fact, not many shared my predictions, which later developments sadly showed to be correct. When I spoke about the matter with Rajchmann, Salter, Monnet and Bogomolov, the Soviet representative, at the local office of the League of Nations in Nanjing eight days before the events in Austria took place, nobody agreed with my view of things. When Tandler was returning from Beijing, I met him at the train station and informed him of the events in Austria. It was difficult for me to see the astonishment and tears in the eyes of this superb man, whose way of managing social welfare and public healthcare matters 
in the city had been an exemplary model for the rest of the world. Nobody could understand the pain and the feelings he felt in those moments as well as me. I understood him when he read about how they were shooting canons to tear down the very workers' housing whose construction he had commissioned for the health wellbeing of the common folk; I understood him when I saw him reading the news about the destruction of his organisation, about the dismissal of people he had raised to perform real health work. How much tragedy at the end of one's life: the fruit of long and carefully planned labour was now a thing of the past.

In Štampar's journal we also find the following mention of Tandler: During my stay in Shanghai, I was also visited by some other people, acquaintances with whom I had previously worked or with whom I had been in connection. Amongst the Europeans, the one I was most fond of was Professor Tandler, who had also come to China the previous year in order to do something in his life at a very unfavourable time. We all know Tandler as a great anatomist and healthcare policy expert, who had taught anatomy at the University of Vienna for no less than 40 years. For the past 12 years, he was a member of the Vienna city administration, the best and most successful of all socialist administrations, whose merits nevertheless could not save it from falling prey to the reactionary forces which triumphed across Europe. It so came to pass that the 65-year-old Professor Tandler came to see the institutions he had created grow derelict and become absorbed by a new spirit, he saw workers' housing bombed and witnessed the suffering of his associates and political leaders. At the first news he received about the events in Vienna, he hurried there by the fastest route, although he knew that what waited for him there was imprisonment and humiliation by the reactionary forces. However, in this regard as well as in others, the situation in Vienna was different to other countries where reactionary forces had gained a foothold. He was met at the border and told that he would be arrested. When he showed up at the Vienna train station, he was once more informed of the exact time when he would be picked up at his residence. At the station, he saw some acquaintances, some of whom avoided him just to stop him from coming near. Having come home, he got ready and took a bath and then later in the evening he was taken to prison. He was not told why he had been imprisoned until they finally fabricated a story according to which he had been involved in planning the upheaval in Vienna in February of the previous year. It is interesting that foreigners stood by Tandler, most of all the American Medical Association who sent a telegram to Dollfuß, asking him about the reasons for Tandler's imprisonment, to which Dollfuß failed to reply. When he later asked journalists, i.e. the representatives of the international press, to visit him and inform him of the authorities' intentions, the main representative of the foreign press refused to come until the Chancellor answered the American Medical Association's inquiry. After 12 days in prison, Tandler was released. The people of Vienna, particularly the common folk for whom he had worked so hard, loved and still love Tandler. Whenever he would show his face on the street, he was cordially greeted. As things always go, his experiences with intellectuals were bad. Everybody avoided him, none of the active university professors so much as asked about him, let alone stood by him. Only Professor Eiselberg and Wagner Jauregg, who had retired long ago, inquired about his destiny. His immediate associates had been relieved of duty. The Jews had all been laid off. It was impossible for him to stay in Vienna, every step he took reminded him of the recent past and his activities: the decay of institutions and their spirit, into which he had invested so much of himself, the suffering of common folk, workers with whom he had grown close and whom he could not help in his present circumstances - all of this had such an effect on the old professor and social worker that he left Vienna last summer and fared off into the world in his old age simply to forget about his sorrow, should that prove to be possible. There is no doubt that Tandler would have found pleasure in new and constructive work once more and that the events in Vienna would have at least faded from his memory if it were not so difficult at his age to adapt to new circumstances and problems, which require different solutions than the problems he faced in Vienna. There is also another kind of trouble which meets such men of action and authority: Tandler was a member of a powerful party which wielded exclusive power in a large city with a competent local administration. He had an authority which nobody could oppose. He was always in his communication and quite galling in his criticism. His direct and dominating manner consequently caused him great difficulties in China, because he forgot that form is more important than the substance of the work done there. It was very hard for me to observe Tandler's psychological distress as he made preparations to once again return to Austria, this time because the government refused to continue paying him his pension if he stayed abroad. This time he arrived to China through America, where he had been invited by the New York University Medical School to hold a series of special lectures in anatomy. He had spent the past two months in Hunan, where he assessed the local medical school and set up an institute for anatomy with the help of his assistant. He had also stayed in Xi'an at the invitation of the Tongji University from Shanghai, who had asked him to look into the possibility of moving the university from Shanghai to Xi'an: he was thrilled with the idea and showed a strong intention to come back here and take part in the establishment of a new medical school on the principles he considered optimal. He asked me to take an interest in the matter and to make some arrangements concerning his arrival. We spent a few days in Shanghai together and this man, whom I found to be exquisite in every regard, made a deep impression on me at all times. Despite his mature age, he believed that he would live to see his ideals triumph. The actions of his political opponents in Vienna had made him very bitter and everything I saw made me realize that he had a keen desire for revenge. What hurt him the most was the destruction of institutions which he had founded and which were without doubt among the best ones established in Europe during the past decade. When I escorted him to the shore one foggy morning, I felt a kind of ache in my heart to see my teacher waving his wide hat at me on the deck of a small boat carrying him down the river, where he was to board an ocean ship. ${ }^{6}$ Working in China was not easy and many obstacles came in one's 
way, especially for an elderly professor who could not easily sever his relations with his old homeland, his family and the work he had previously done. In a letter from 1935 sent to Tandler's address in Vienna, Štampar explains to him once more the current situation in China in connection to a new offer for cooperation sent to Tandler: ...in the meantime, you must have received the invitation. It was my wish to expressly let you know my opinion on this... The people in Nanjing have the best intention to establish a good medical school; they have invited you based on that outlook, although those same people did not treat you very nicely last year; naturally, we also need to take into account the Chinese character to be able to better understand many things; however, of course, we are never going to have full disclosure of the forces which were in play then; let us leave those things to the past. First, I will tell you something about the invitation sent to you. From that invitation you may see that you will actually have two missions, one at the Military Medical School and the other at the Central University School; both sides will contribute the same amount of money for your remuneration; although it thus seems at first sight that you will have to serve two masters, that is only formally the case, in my opinion, because both schools are actually supervised by Dr Liu; thanks to his influence, Dr Cheer has been appointed dean of the medical school at the Central University, seeing as he belongs to its staff; that means that you will in reality mostly deal with Dr Liu. It would not make much sense for me to write to you about Dr Liu, as you already know him very well; he is very alien to our ideology and that is something we must come to grips with; his wish is to do something good for China and the matter is one of a personal rather than a Chinese nature for him; in his heart of hearts he has a dislike of foreigners, especially those with stronger personalities; he prefers the foreigners which belong to his circle; I do not believe that he could be changed; he is the way he is and will stay that way. These are the things you need to bear in mind before you make your decision; nevertheless, I trust you will not have any moral difficulties if you only dedicate yourself to the task assigned to you; I believe that you will receive the funding necessary for the implementation of your programme despite the difficult financial situation... Another thing concerning my situation; despite Dr Liu's objections, I have managed to make certain progress in the provinces; I am now travelling southwest at the invitation of the provincial governments; it seems that the work in the west has taken root and I have very friendly relations to the people working there. I hope to have similar success on this journey, as well. However, the organisation of local activities by the League of Nations is so dismal that the value of all my success eventually and ultimately declines to a terrific degree; we are here to do something but we neither have a real mission nor any contact with the other branches of the League of Nations, like some forgotten children in a distant land; we receive excessive salaries but we mostly do little work; you must surely know how I feel and with whom my sympathies in China lie - not with the authorities but with the repressed people; however, all my activity completely depends on some individuals who are as fickle as the weather. I have not received any answer to my requests from Geneva for months, yet without intellectual engagement in one's work it is impossible to do good things and have lasting success; because of my ideological inclination, with which Dr Liu is well familiar, I have been having many difficulties with him; as you know, my work is not limited to one particular part of our profession but is rather of a general nature and in this sort of situation many difficulties arise... On the whole, there are still various possibilities for useful work here; however, only those who not only have great experience but also the moral strength to overcome many extraordinary difficulties are capable of performing the tasks ahead while still maintaining a fresh spirit and never sinking into pessimism. You possess those wonderful qualities; I told you all there is to say the way my conscience deemed it proper; think about it, my dear teacher, and decide upon it to the best of your knowledge and feeling. ${ }^{17}$

Tandler also receives correspondence concerning his repeated engagement in China from Berislav Borčić, Štampar's closest associate, director of the School of Public Health in Zagreb and LNHO expert who also worked in China, where he once led the Nanjing Institute of Hygiene. In 1935, Borčić writes to Tandler in Vienna: I have been infomed that you have in principle agreed to take up a position at the Faculty of Medicine in Nanjing. I hope that you will give your definite consent and spend some years working in Nanjing. As I have learned, the gentlemen in Nanjing would be singularly pleased if you were to accept the offer and are ready to help you not only in the implementation of anatomy courses but also in the general work on the organization of the new faculty. Štampar is also very much looking forward to your arrival, although he does also have certain concerns, just like I do, because we know how difficult it is to cope with our Chinese friends. Štampar will stay in Nanjing most likely until March or April 1936, which would mean that you will still be able to meet him there, should you go to China. I will stay in Zagreb for some time, although I have received invitations from Nanjing and Geneva to return to Nanjing. ${ }^{18}$

Štampar writes about the possibility of Tandler's return to China in his journal, stating the following: Professor Tandler has got in touch with me, too. He has once again been invited to Nanjing to spend two years organizing the Department of Anatomy at the newly established medical school, as well as at the Military Medical School in Nanjing. In his letter to me, he tells me that he must go abroad despite his old age because he cannot stand the mood in the city where he had so successfully worked for a number of good years. I was impressed by the content of the letter and I spent a long time thinking about my teacher, whose fate I share myself. Everything tells me that Tandler will accept the invitation sent to him because he still wants to create something in the autumn of his life. By the measure of his enthusiasm and optimism, he is still a young man, though he is now well into his sixties. He has received several offers to work in foreign parts but it seems to me that he likes the Far East because of its potential, even in the darkest of times, and that he expects to find some possibilities for useful work here. ${ }^{6}$ 
This offer to work in foreign parts, as will soon become clear, had arrived from the USSR, where Štampar himself travelled to, as well, just before the summer of 1936, leaving from Manchuria by Trans-Siberian Railway on his way to Moscow. He had done so at the invitation of the Commissariat for Public Health Protection of the USSR, in connection to the issue of hygiene standards in rural areas. A meeting of experts working for the League of Nations was scheduled to take place on the 15th of July 1936 in Moscow and was attended by many other public health experts from abroad, as well, such as Jacques Parisot and Ludwik Rajchmann as the director of the LNHO. The participants of the meeting were also temporarily joined by Selskar Gunn, a member of the staff of the Rockefeller Foundation. Of course, Tandler found himself in Moscow, too, having come there in February 1936 at the invitation of the Soviet government.

Štampar does not fail to record the following in his journal: ...I had particularly been looking forward to dear Tandler, who came to the train station to welcome me but could not wait until the small hours of the night for my train, which had been running very late. Nevertheless, I met him the following morning and we could not get enough of our conversation. He had come to Moscow in February at the invitation of the Soviet government and, from what I saw, he was well-received. He was commissioned with overseeing the development of plans for a vast construction programme by the Commissariat for Public Health. He is staying at a hotel and does still not have his own office. He is thrilled with the reconstruction work being done by the Soviet Union but he complained to me about the bureaucracy stifling many things. According to his view of things, there are still some remnants of the imperial bureaucratic system left in the administration and it will take a long time for the administration to be cleansed of that spirit. He told me that was how things had gone for them in Austria, too: they had had extraordinary plans but the Austrian imperial bureaucracy ruined many things. There are not many foreigners in the health service, at least in the headquarters, because the experiences they had with foreigners had reportedly been unfavourable. Seeing as Tandler had entered office in the Soviet administration, the Austrian government renounced his right to a pension, which is why he is now pondering how to bring his family here, because it was hard for him on his own. He has a two-year contract with a monthly salary of 2000 roubles, while his apartment at the hotel is paid for from the office budget. According to his words, this salary is enough for him as a foreigner... ${ }^{6}$

Štampar writes that, during the two days of his stay in Moscow, he had the opportunity to see the city and the immediate surroundings. The good Tandler took me for a ride outside the city in the evening. We were both amazed by the tremendous amount of activity in all directions... ${ }^{6}$ Stampar and Tandler spent time together in the USSR in June and July 1936, while only a month later, in August 1936, Tandler passed away. Writing about Tandler in his journal with great nostalgia for his friend, Štampar says: and I was left without him in a large country to roam, to work, to cry and to laugh. ${ }^{6}$

\section{Conclusion}

Štampar indeed continued to work and stand for the ideas which had shared with his professor Julius Tandler. However, the opportunities for constructive work in the field of public health grew increasingly slim in the political constellation of the time. The League of Nations was losing its power and its health organisation followed suit. The local resistance to foreign influences in China was becoming progressively intense. The ever more severe unrest led the world into World War II and pushed the establishment of an international public health order to the margins for some time to come. However, what remained in memory was a flow of ideas and experiences which had been formed in Central and Southeastern Europe and which subsequently tried to make their way far to the East and develop not only local but also general and international qualities. Many of these ideas became the basis for a new world-wide public health system that developed after World War II.

This Research EMERged as Part of a Project Funded by the Croatian Science Foundation, Nr 5974, Transition of Croatian Elites form the Habsburg Monarchy to the Yugoslav State, led by Iskra Iveljić.

\section{LITERATURE:}

1. Hiller S.M, Jewell J.A., Health Care and Traditional Medicine in China 1800-1982, London, Routledge, 1983.

2. Yip K., Health and National Reconstruction in Nationalist China, Michigan, Association for Asian Studies, 1995.

3. Borowy I. (ed.), Uneasy Encounters: The Politics of Medicine and Health in China 1900-1937, Frankfurt am Main, Peter Lang, 2009. 4. Dugac Ž., Public health experiences from interwar Croatia (Yugoslavia) and making Western medicine in the 1930s China. Acta Med Hist Adriat 2018; 16(1); pp. 75-106.

5. Letter, Štampar to Tandler, Geneva, 26 July 1933, correspondence between Tandler and Štampar, archive of the Institut für Geschichte der Medizin-Josephinum, Vienna (AIGM).

6. Dugac Ž. - Pećina M. (eds.), Andrija Štampar: Dnevnik s putovanja 1931-1938, Zagreb, HAZU, Srednja Europa, Škola narodnog zdravlja Andrija Štampar, 2008, pp. 734-735; 193-194; 266-267; 444-446;

\section{$512 ; 670-671 ; 676 ; 267$}

7. Julius Tandler, Archiv der Universität Wien, Vienna (AUW), 27 July 1895, Promotionsprotokoll M.33.6-33.9., p. 571.

8. Sablik K., Julius Tandler: Mediziner und Sozialreformer: eine Biographie, Vienna, A. Schendl, 1983.

9. Hubensdorf, M. \& Ludwig Teleky. Unpublished manuscript in preparation, kindly provided by the authors.

10. Andrija Štampar, AUW, Nationale. Mediziner-Winter-Semester 1910-11, (S).0

11. Andrija Štampar, AUW, 23. Dezember 1911, Promotionsprotokoll M.33.6-33.9., p. 571.

12. Dugac Ž., Andrija Štampar (1888-1958): Resolute Fighter for Health and Social Justice. In: Borowy I., Hardy A. (ed.), Of Medicine and Men: Biographies and Ideas in European Social Medicine between the World Wars, Frankfurt am Main, Peter Lang, 2008.

13. Dugac Ž., Protiv bolesti i neznanja: Rockefellerova fondacija u 
međuratnoj Jugoslaviji. Zagreb: Srednja Europa, 2015.

14. Letter, Tandler to Štampar, Vienna, 9 May 1933, Correspondence between Tandler and Štampar, AIGM.

15. Letter, Štampar to Tandler, Zemun, 20 May 1933, Correspondence between Tandler and Štampar, AIGM. Letter, Štampar to

Tandler, Zemun, 20 May 1933, Correspondence between Tandler and Štampar, AIGM.

16. Letter, Štampar to Tandler, Nanjing, 28 October 1933, Correspondence between Tandler and Štampar, AIGM.

17. Letter, Tandler to Štampar, Hong Kong, 2 October 1935, Correspondence between Tandler and Štampar, AIGM.

18. Letter, Borčić to Štampar, Zagreb, 21 October 1935, Correspondence between Tandler and Štampar, AIGM. 